\title{
A rare complication of acute otitis media in childhood: peripheral facial palsy
}

\section{Introduction}

Peripheral facial paralysis (PFP) is rarely seen in childhood. It is not frequently observed in pediatric emergency services. The incidence rate of PFP in children varies from 5 to $21: 100,000 / y e a r$. It is mostly seen between 5 and 11 years of age and there is no significant difference between the male and female. ${ }^{1}$ Bell's palsy (idiopathic) is postulated in $26-76 \%$ of all cases. ${ }^{2,3}$ Infectious, neoplastic, traumatic, iatrogenic, toxic, syndrome(e.g. Melkerssone Rosenthal Syndrome, Möbius Syndrome), neuroinflammatory, hypertensive and other reasons are among etiologic causes. ${ }^{4,5}$ The most common proven etiology is Lyme borreliosis causing $30 \%$ to more than $50 \%$ of all cases, depending on the season. ${ }^{1}$ PFP may present as a rare complication of acute otitis media (AOM). AOM is the second most common infectious disease after acute tonsillopharyngitis in childhood. The frequent use of antibiotics reduces the incidence of intracranial and extracranial complications secondary to AOM. ${ }^{6}$ Anti-biotherapy, steroid treatment, exercise and physical therapy modalities are recommended for treatment of PFP secondary to AOM.The 14-month-old girl was brought to our outpatient clinic by her mother with the complaints of failure to close her right eye and asymmetry on her face. On physical examination, the patient was not able to pull the right lip corner during crying, the right nasolabial sulcus was faint, the right eye could not be closed, and there was no blink reflex (Figure 1). The patient was diagnosed as stage V PFP according to the Hause-Brackman classification (Table 1). Consultations on pediatrics, otorhinolaryngology and ophthalmology were requested and after evaluations PFP secondary to AOM was detected in the patient and antibiotic and steroid treatments were started by otorhinolaryngologist. Treatment including hot compress and massage were suggested to the patient and the family was educated regarding these modalities and home exercise program. She responded the treatment in a short period and after a three weeks period perceivable improvement was obtained with these modalities (Stage II according to the House-Brackman classification, (Figure 2) and oral medication was stopped stepwise while other modalities were continued. Written consent was obtained from the parents.

We considered the patient as PFP due to AOM. Mainly affecting the tympanic cavity and mastoid, while structures adjacent to the middle ear such as facial nerve bony canal may also be affected by the inflammatory process and this effect may result in facial paralysis. ${ }^{7}$ There are few known etiologies of this condition, but some hypotheses described below may explain the situation.

i. Retrograde infection within the facial nerve bony canal or retrograde infection within the tympanic cavity ascending the chorda tympani to the facial nerve. ${ }^{8}$

ii. Reactivation of latent virus infection caused by middle ear suppuration. ${ }^{9}$

iii. Demyelination of the facial nerve secondary to the presence of bacterial toxins. ${ }^{10}$

iv. Acute neuritis with venous thrombosis leading to inflammatory edema of the nerve. ${ }^{11}$
Volume 3 Issue I - 2018

Canan Çelik, Adem Türköz, Elif Uysal, Ilker Ilhanlı, Fazıl Kulakli

Department of Physical Medicine and Rehabilitation, Giresun University, Turkey

Correspondence: Fazil Kulakli, MD, Asst. Prof, Department of Physical Medicine and Rehabilitation, Giresun University Dr Illhan Özdemir Training and Research Hospital, Giresun, Turkey, Tel +904543101600, Fax +904543101699, Email drfz146@gmail.com

Received: January 02, 2017 | Published: January 24, 2018

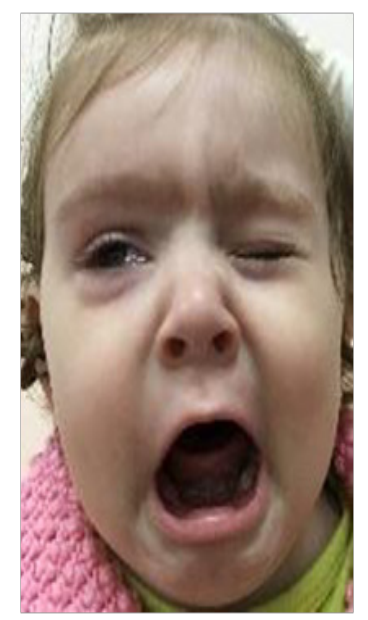

Figure I Before treatment (stage V PFP according to the house-brackman scale).

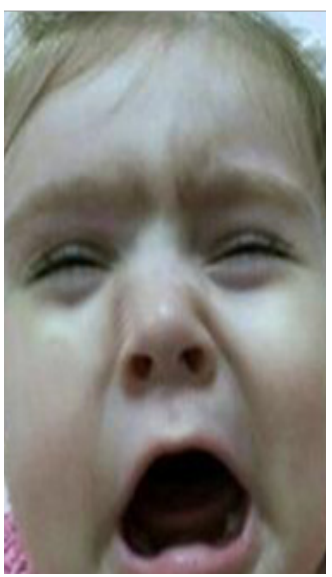

Figure 2 After treatment (stage II PFP according to the house-brackman scale). 
Table I House brackmen scale

\begin{tabular}{|c|c|c|c|c|c|}
\hline \multicolumn{6}{|c|}{ Characteristics } \\
\hline Grade & Description & Gross & At Rest & Motion & $\begin{array}{l}\text { Estimated- } \\
\text { function (\%) } \\
\text { I I)0 } 80\end{array}$ \\
\hline $\mathrm{i}$ & normal & normal & normal & normal & 100 \\
\hline ii & $\begin{array}{l}\text { mild } \\
\text { dysfunction }\end{array}$ & $\begin{array}{l}\text { slight weakness noticeable on dose } \\
\text { inspection, may have very slight } \\
\text { synkinesis }\end{array}$ & $\begin{array}{l}\text { normal } \\
\text { symmetry \& } \\
\text { tone }\end{array}$ & $\begin{array}{l}\text { forehead: moderate } \\
\text { to good function: eye: } \\
\text { complete Closure w/ } \\
\text { minimum effort mouth: } \\
\text { Slight asymmetry }\end{array}$ & 80 \\
\hline $\mathrm{iii}$ & $\begin{array}{l}\text { moderate } \\
\text { dysfunction }\end{array}$ & $\begin{array}{l}\text { Obvious but not drshguring Terence } \\
\text { between } 2 \text { sides; noticeable but not } \\
\text { severe synkinesis, contracture. and/ } \\
\text { or hemifacial spasm }\end{array}$ & $\begin{array}{l}\text { normal } \\
\text { symmetry \& } \\
\text { tone }\end{array}$ & $\begin{array}{l}\text { Forehead' slight to } \\
\text { moderate movement, eye: } \\
\text { complete closure viil } \\
\text { effort: mouth. slightly weak } \\
\text { w/ maximum effort }\end{array}$ & 60 \\
\hline iv & $\begin{array}{l}\text { moderately } \\
\text { severe } \\
\text { dysfunction }\end{array}$ & $\begin{array}{l}\text { obvious weakness and/or disfiguring } \\
\text { asymmetry }\end{array}$ & $\begin{array}{l}\text { normal } \\
\text { symmetry \& } \\
\text { tone }\end{array}$ & $\begin{array}{l}\text { forehead: none: eye: } \\
\text { incomplete closure: mouth: } \\
\text { asymmetric w/ maximum } \\
\text { effort }\end{array}$ & 40 \\
\hline$v$ & $\begin{array}{l}\text { severe } \\
\text { dysfunction }\end{array}$ & only barely perceptible motion & asymmetry & $\begin{array}{l}\text { forehead: none: eye: } \\
\text { incomplete closure; mouth } \\
\text { slight movement }\end{array}$ & 20 \\
\hline vi & Total paralysis & no movement & asymmetry & no movement & 0 \\
\hline
\end{tabular}

Because the prevalence of PFP secondary to AOM is low, the choice of treatment is also difficult. Most authors recommend aggressive antibiotic therapy (The most common agents are Streptococcus Pneumoniae and Haemophilus Influenzae) and myringotomy therapy with or without tube insertion. ${ }^{6}$ In addition, steroid treatment is also recommended for facial paralysis. ${ }^{12}$

\section{Conclusion}

With this case, it is emphasized that PFP occur rarely after AOM and can respond the early treatment. PFP which is rarely seen in childhood may present as a rare complication of AOM. The treatment including antibiotics, exercise, hot compress and massage can be used to get early response.

\section{Acknowledgements}

None.

\section{Conflict of interest}

The author declares no conflict of interest.

\section{References}

1. Drack FD, Weissert M. Outcome of peripheral facial palsy in children - A catamnestic study. Eur J Paediatr Neurol. 2013;17(2):185-191.

2. Christen H-J, Hanefeld F, Eiffert H, et al. Epidemiology and clinical manifestations of Lyme borreliosis in childhood. A prospective multicentre study with special regard to neuroborreliosis. Acta Paediatrica Supplement. 1993;386(82):1-75.
3. Chen WX, Wong V. Prognosis of bell's palsy in childrendanalysis of 29 cases. Brain \& Development. 2005;27(7):504-508.

4. May M, Schaitkin BM. Editors. The facial nerve, May's second edition. 2nd ed. New York: Georg Thieme Verlag; 2000.

5. White NMKM. Facial paralysis secondary to acute otitis media. Pediatric Emergency Care. 2000;16(5):343-345.

6. Gaio E, Marioni G, Filippis C de, et al. Facial nerve paralysis secondary to acute otitis media in infants and children. Child Health. 2004;40(8):483486.

7. Ellefsen B, Bonding P. Facial palsy in acute otitis media. Clin. Otolaryngol. 1996;21(5):393-395.

8. Kamitsuka M, Feldman K, Richardson M. Facial paralysis associated with otitis media. Pediatr Infect Dis J. 1985;4(6):682-684.

9. Joseph EM, Sperling N. Facial nerve paralysis in acute otitis media: cause and management revisited. Otolaryngol Head Neck Surg. 1998;118(5):694-696.

10. Elliott CA, Zalzaal GH, Gottlieb WR. Acute otitis media and facial paralysis in children. Ann Otol Rhinol Laryngol. 1996;105(1):58-62.

11. Jacobsson M, Nylen O, Tjellstrom A. Acute otitis media and facial palsy in children. Acta Paediatr Scand. 1990;79(1):118-120.

12. Lorch M, Teach SJ. Facial nerve palsy: etiology and approach to diagnosis and treatment. Pediatr Emerg Care. 2010;26(10):763-769. 